\title{
New Species of Ostracoda Genus Cytherella Jones, 1849 from the Upper Cretaceous of Hamrin Area North Eastern Iraq
}

\author{
Waleed Y. AL - Ubide \\ Remote Sensing Center \\ Mosul University
}

\author{
Saleh K. Khalaf \\ Geology Department \\ College of Science \\ Mosul University
}

(Received 13/4/2009, Accepted 8/4/2010)

\begin{abstract}
Four new ostracod species belonging to the genus Cytherella Jones, 1849 described from the Upper Cretaceous succession of Hamrin area NE Iraq namely: Cytherella shiranishensis sp. nov; ; C. iraqiensis sp. nov.: C. mushoriensis sp. nov.; and $C$. kirkukiensis sp. nov.
\end{abstract}

Keywords: Ostracoda; Cytherella; Cretaceous; Iraq.

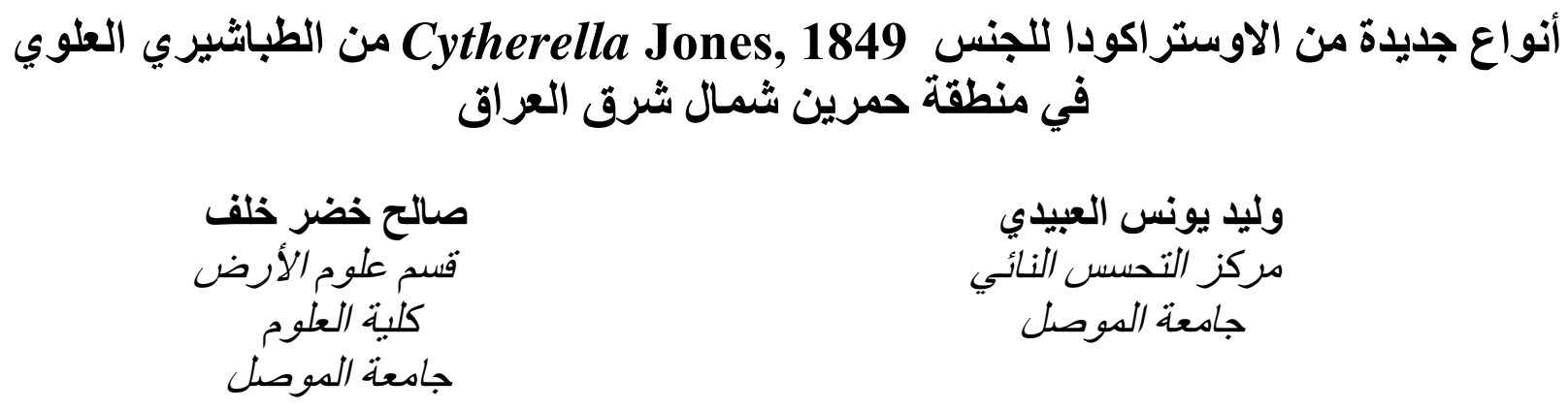

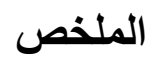

Cytherella Jones,1849 تم وصف أربعة أنواع جديدة من قثريات الاوستر اكودا تعود للجنس و التي شملت الأنو اع التالية : Cytherella shiranishensis sp. nov; C. iraqiensis sp. nov: C. mushoriensis sp. nov.; and $C$. kirkukiensis sp. nov. .

$$
\text { وتم وصفها من الطباثشيري العلوي لمناطق شمال العر اق. }
$$




\section{INTRODUCTION}

The present paper is part of study investigated Upper Cretaceous succession (Santonian - Maastrichtian) from Khashab oil well No. 1, Hamrin Area (Fig, 1, 2) NE Iraq (Al-Ubide, 1989) at depth (2100-3600)m, where the study covered the following formations:

1- Shiranish Fm. ( Upper Campanian-Maastrichtian)

2- Mushorah Fm. (Lower Campanian)

3- Kometan Fm. upper part of (Upper Santonian).

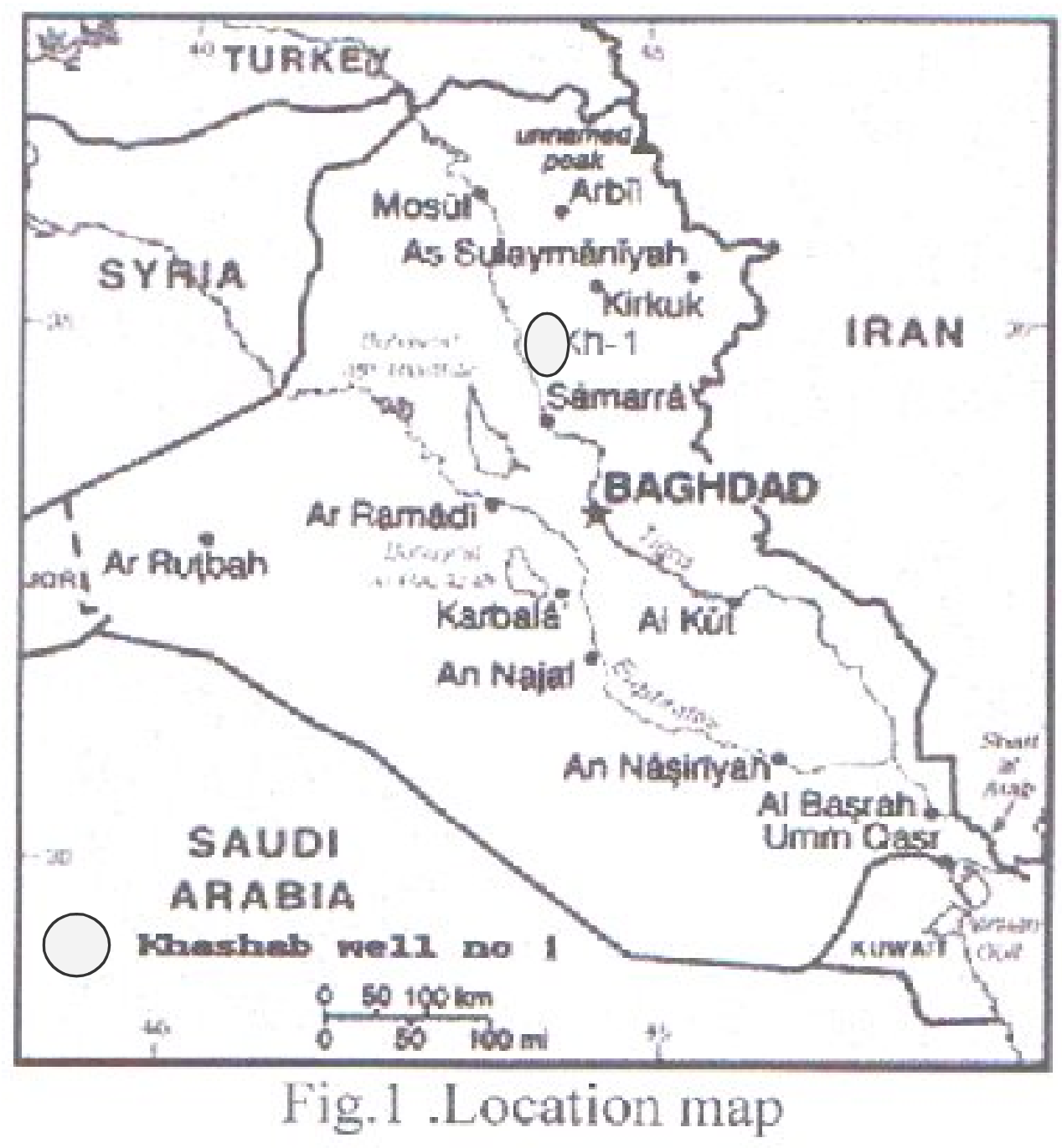




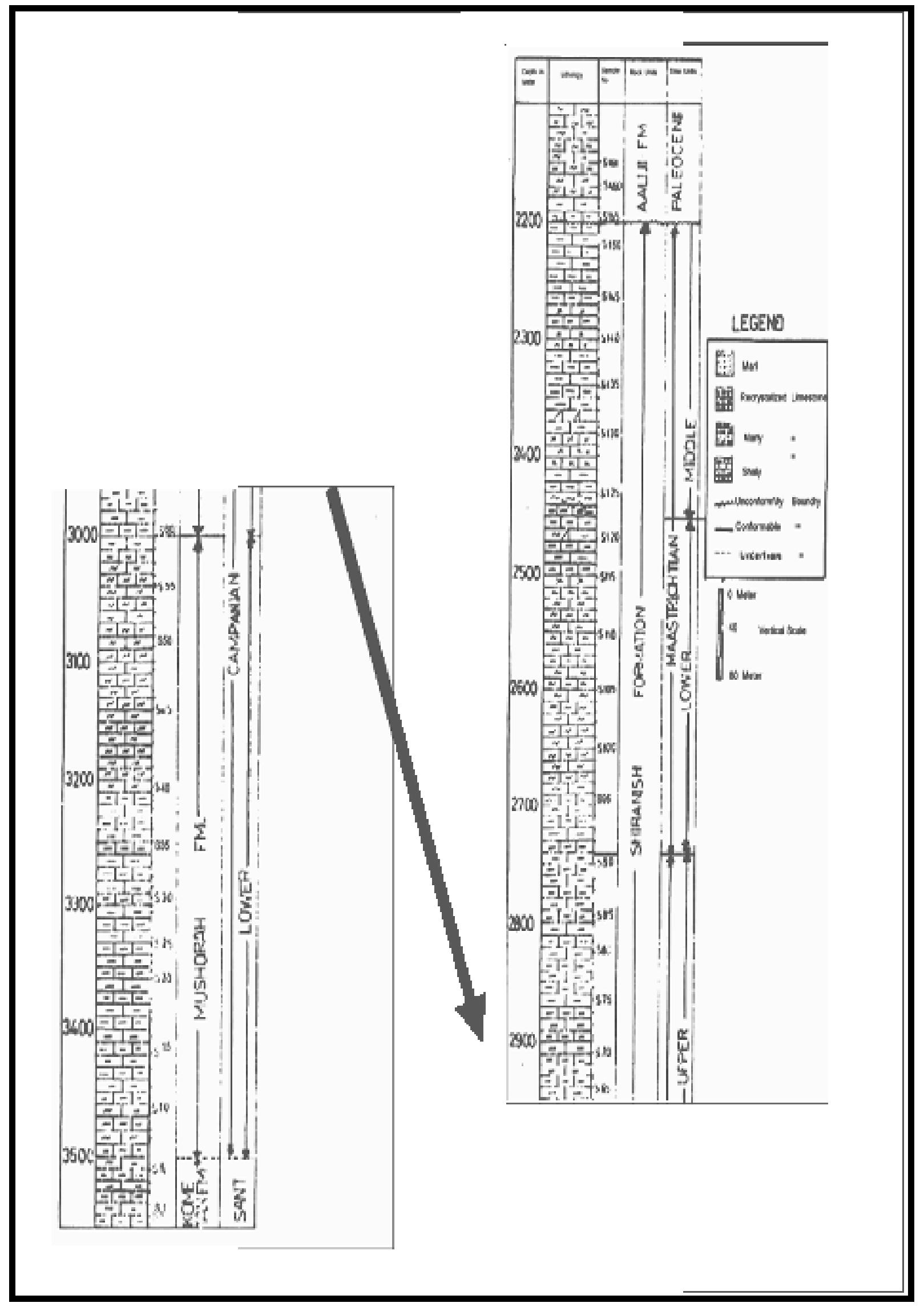

Fig. 2 : Stratigraphic sequences and location of samples, well Khashab No. 1 


\title{
Repository:
}

Al the figured specimens are deposited in the Mosul University, Geology Dept. Cretaceous collection with the prefix Mo. Cret.

\begin{tabular}{lll}
\multicolumn{3}{c}{ SYSTEMATIC DESCRIPTIONS } \\
Subclass & Ostracoda & Latrielle, 1806 \\
Order & Podocopida & Muller, 1894 \\
Suborder & Platycopa & Sars, 1866 \\
Family & Cytherellidae & Sars, 1866 \\
Genus & Cytherella & Jones, 1849
\end{tabular}

Type Species: Cytherina ovata Roemer 1840

\section{Cytherella shiranishensis sp. nov.}

\author{
pl. 1, Figs. 1,2
}

Derivation of name: From it is occurrence in the Shiranish Formation

Holotype: Carapace Mo. 1 Crt. 5

Paratypes: Carapace Mo. 1 Crt. 6

Type Horizon: Shiranish Formation (U. Campanian), Hamrin area

Material: Twenty six carapaces

Diagnosis: A species of the ostracode genus Cytherella with narrow posterior end pointed at the middle in the right valve. Dorsal margin strongly convex in the right valve with distinctive overlapping of left valve.

Description: Carapace sub-ovate in lateral view, maximum height at the middle of the carapace, greatest length at the middle of the carapace. Anterior end well rounded, Posterior end pointed at the middle in the right valve. Dorsal margin strongly convex in the right valve, slightly in the left. Right valve larger than the left; overlapping distinctive along all margins. Ventral margin convex in the right 
valve nearly straight in the left. In dorsal view carapace sub-ovate with compressed anterior end, thickest part at the last third of the carapace. Lateral surface smooth Dimensions of figured specimens $(\mathrm{mm})$ :

Carapace Mo. Crt. 5 Pl. 1 Fig. $1 \quad 0.83 \quad 0.50 \quad 0.4$

Carapace Mo. Crt. 6.1 pl.1 Fig. $2 \quad 0.80 \quad 0.49 \quad 0.4$

Remarks: The present species is fairly similar to Cytherella ovata Roemer (in Grekoff 1951) from the U. Cretaceous of France, but differs in having narrower posterior end, and strongly convex dorsal margin in the right valve, Cytherella aff. poserodorsodirecta Andreu, 1991 (in Damotte, 1995)from Upper Cretaceous of Pacific ocean shows similarities to the present species but it differs in having strongly convex dorsal margin and in the degree of overlapping around all margins. Cytherella IRC 6 Grosdidier 1973 from the Santonian of Iran differs from Iraqi species in having nearly straight dorsal and ventral margins.

\section{Cytherella iraqiensis sp. nov.}

\section{pl. 1, Figs. 3,5}

Derivation of name: from it is first description in Iraq.

Holotype: Mo. 1 Crt. 7

Paratype: Mo. 1 Crt. 8

Type Horizon: Upper Campanian, Shiranish Formation, Hamrin area.

Material: Seventy five carapaces.

Diagnosis: Carapace Sub-ovate in lateral view, posterior end strongly narrower than the broadly rounded anterior end.

Description: Ovate Carapace in lateral view broadly rounded, anterior end tapering towards strongly narrower posterior end. Dorsal margin broadly convex than the ventral margin. Maximum height at the middle of the dorsal margin, greatest length passes through mid height. Right valve larger than the left, overlapping more prominent along the dorsal and ventral margins. Lateral surface 
smooth. In dorsal view carapace compressed anteriorly, rounded posteriorly, maximum width at the posterior end.

Dimensions of figured specimens (mm): $\quad \underline{\mathrm{L}} \quad \underline{\mathrm{H}} \quad \underline{\mathrm{W}}$

Carapace Mo. 1. Crt. 7, pl. 1, Fig. $3 \quad 0.63 \quad 0.42 \quad 0.33$

Carapace Mo. 1. Crt. 8.1, pl. 1, Fig. $4 \quad 0.63 \quad 0.40 \quad 0.33$

Carapace Mo. 1. Crt. 8.2, pl. 1, Fig. $5 \quad 0.53 \quad 0.40 \quad 0.28$

Remarks: The present species shows similarities to Cytherella OUM 1110 Grekoff, 1969 from the Maastrichitian of Algeria, but differs in having distinctive narrower posterior end, while the Algerian species characterized with broad rounded posterior end. Grosdidier( 1973) recorded Algerian species from the Santonian - Maastrichitian of Iran.

The Iraqi species shows affinities to Cytherella Sp. 1 Babinot et al., 1988 from the Santonian- Campanian of Senegal but differs in having broadly rounded anterior end with more conspicuous overlapping.

The present species shows similarities to Cytherella shiranishensis sp. nov. from the present study but it differs in having broadly rounded anterior and posterior ends.

\section{Cytherella mushoraiensis sp. nov.}

$$
\text { pl. 1, Figs. } 6,7
$$

Derivation of name: From it is occurrence in the Mushorah Formation, Hamrin, NE Iraq.

Holotype: Mo. 1 Crt. 9

Paratypes: Mo. 1 Crt. 10

Type Horizon: Lower Campanian, Mushorah Formation, Hamrin area.

Material: Nine carapaces.

Diagnosis: A species of the genus cytherella characterized with narrower, obliquely rounded posterior end, shallow sulcus present at the maximum height, concave ventral margin in the middle. 
Description: Carapace elongate sub-ovate in lateral view, carapace tapering toward posterior end. Anterior margin broadly rounded posterior narrowly rounded. Dorsal margin convex at maximum height, gently sloping toward the posterior end. Ventral margin strongly concave at the middle maximum length passes through mid point. Lateral surface smooth with shallow sulcus at maximum height extending towards the posterior end. Right valve larger than left overreaching along the dorsal margin. In dorsal view carapace with compressed anteriorly and posteriorly ends .maximum thickness at the middle of the carapace.

Dimensions of figured specimens (mm): $\underline{L} \quad \underline{H} \quad \underline{W}$

Carapace Mo. 1. Crt. 9, pl. 1, Fig. $6 \quad 0.63 \quad 0.36 \quad 0.26$

Carapace Mo. 1. Crt.10, pl.1, Fig. $7 \quad 0.72 \quad 0.50 \quad 0.40$

Remarks: The present species shows similarities to Cytherella sp. Aff. $C$. unabashsi Alexander, 1932 recorded by Van Den Bold, (1964) from the U. Turonian of Egypt, but the latter differs in having convex dorsal margin in the anterior part with narrow anterior end.

Cytherella Sp.2 Colin et al., 1982 from the Turonian of Spain differs in having narrower anterior end in addition to nearly straight ventral margin.

\section{Cytherella kirkukiensis sp. nov. pl. 1, Figs. 8,9}

Derivation of name: From it is occurrence in the Kirkuk area, North Iraq, Holotype: Carapace Mo. 1 Crt. 11

Paratypes: Carapace Mo. 1 Crt. 12

Type Horizon: Lower Campanian, Mushorah Formation, Hamrin area NE Iraq.

Material: Nine carapaces.

Diagnosis: Carapace elongate, ovate in lateral view with well rounded anterior and posterior ends. 
Description: Ovate, elongate Carapace in lateral view, regularly and well rounded anterior and posterior ends. Maximum height just behind the middle of the Carapace, greatest length at the middle of the maximum height, Dorsal margin slightly convex ventral margin nearly straight, Right valve large than the left, overlapping seen along the dorsal and ventral margins.

Dimensions of figured specimens:

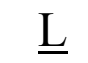

$\underline{\mathrm{H}}$

$\underline{\mathrm{W}}$

Carapace Mo. 1. Crt. 11, pl.1, fig. 8

0.75

0.40

0.28

Carapace Mo. 1. Crt. 12, pl. 1, fig. 9

0.64

0.38

0.22

Remarks: The present species shows similarities to the Cytherella barbatharensis Neale and Singh, 1985 from the Paleocene of India, but differs in having different shape of posterior and anterior ends.

Cytherella IRC 22 Grosdidier, 1973 from the Santonian deposits in Iran differs in having wider anterior end and narrower posterior end.

\section{REFERENCE}

Alexander, C.L., 1929. Ostracoda of the Cretaceous of North Texas. Univ. Texas Bull., Vol. 2907, 137 p.

Al-Ubide, W.Y., 1989. Upper Cretaceous Ostracoda from well khashab No. 1, Hamrin Area, Northeastern Iraq. M.Sc. Thesis, Mosul Univ., 156 p.

Babinot, J.F., Nichaud, L., and Flietiacus-Dupin, F., 1988. Micropaleontological

(Ostracodes, Palynofloras) and Sedimentological studies in the Upper Cretaceous of Djifere and Nema-Ding borehole (Senegal) Bull. Centers Resh.Explor.Procd.Elf-Aquitaiane, Vol. 12, No. 1, pp. 143 - 163.

Colin, J. P., Lamolda, M. A., and Rodriguez Lazaro, JM., 1982. Les Ostracodes Del Cenomaniense Superiory Turoniense DelaCuenc, VasceContabrica. Rev. Esp. De Micropal. Vol. 4, No. 1, pp. 187 - 220. 
Damotte, R. 1995. The biostratigraphy and palaeobiogeography of the Upper Cretaceous-basal Tertiary ostracodes from North Africa, Mali and Congo. Cretaceous Res., Vol. 16, pp.35 - 366.

Grekoff, N., 1951. Quelquse Ostracodes nouveaux du Cameron. Revue. Inst. Fra. Petrol., Vol. 2, pp. 55 - 59 Senonin Supperiour du

Grekoff, N., 1969. Surla Valure Stratigraphique Etles Relastions

Paleogeographiques de quelques Ostracodes du Cretace du Paleocene et de Eocene Inferiour d' Algerie Orrental. Proc. of $3^{\text {rd }}$ African Micropal. Coll. pp. 227 - 248.

Grosdidier, E., 1973. Association de Ostracodes du Cretace de Iran. Rev. Inst. France Petrol Vol. 28, No. 2, pp. $131-169$.

Neale, J. W. and Singh, P., 1985. Ostracoda from the Middle Eocene of Assam. Paleontology, Vol. 28, No. 2, pp. 355 - 385.

Van Den Bold, W. A., 1964. Ostracoda, aus der Oberkreide Van Abu Rawash, Egypten. Palaeontographica Abst., No. 123, pp. 111 - 130.

\section{Plate-1}

\section{Figs. $(1,2)$ Cytherella shiranishensis sp. Nov}

(1) Lateral view of left valve (Mo.1 Crt.5) Shiranish Fm.(2918-2919)m.X.63

(2)Dorsal view of the carapace (Mo.1Crt.6) Shiranish Fm. (2833-2834) m.X.70.

Figs. (3-5) Cytherella iraqiensis sp.nov.

(3) Lateral view of left valve (Mo.1 Crt.7) Shiranish Fm. (2918-2919) m.X.75.

(4) Lateral view of right valve (Mo.1Crt.8.1) Shiranish Fm. (2818-2819) m. X.70.

(5)Dorsal view of the carapace (Mo.1Crt.8.2) Shiranish Fm. (2960-2961) m.X.83

Figs. $(6,7)$ Cytherella mushoraiensis sp.nov.

(6) Lateral view of left valve (Mo.1 Crt.9) Mushorah Fm.(3418-3419)m. X.70.

(7)Dorsal view of the carapace (Mo.1Crt.10) Shiranish Fm. (2860- 2861) m.x.65.

Figs. $(8,9)$ Cytherella kirkukiensis sp. nov.

(8) Lateral view of left valve (Mo.1 Crt.11) Mushorah Fm.(3403-3404)m.X.69.

(9)Dorsal view of the carapace (Mo.1Crt.12) Shiranish Fm.(2874-2875)m.X.75 
Waleed Y. AL - Ubide and Saleh K. Khalaf

\section{PLATE -1}

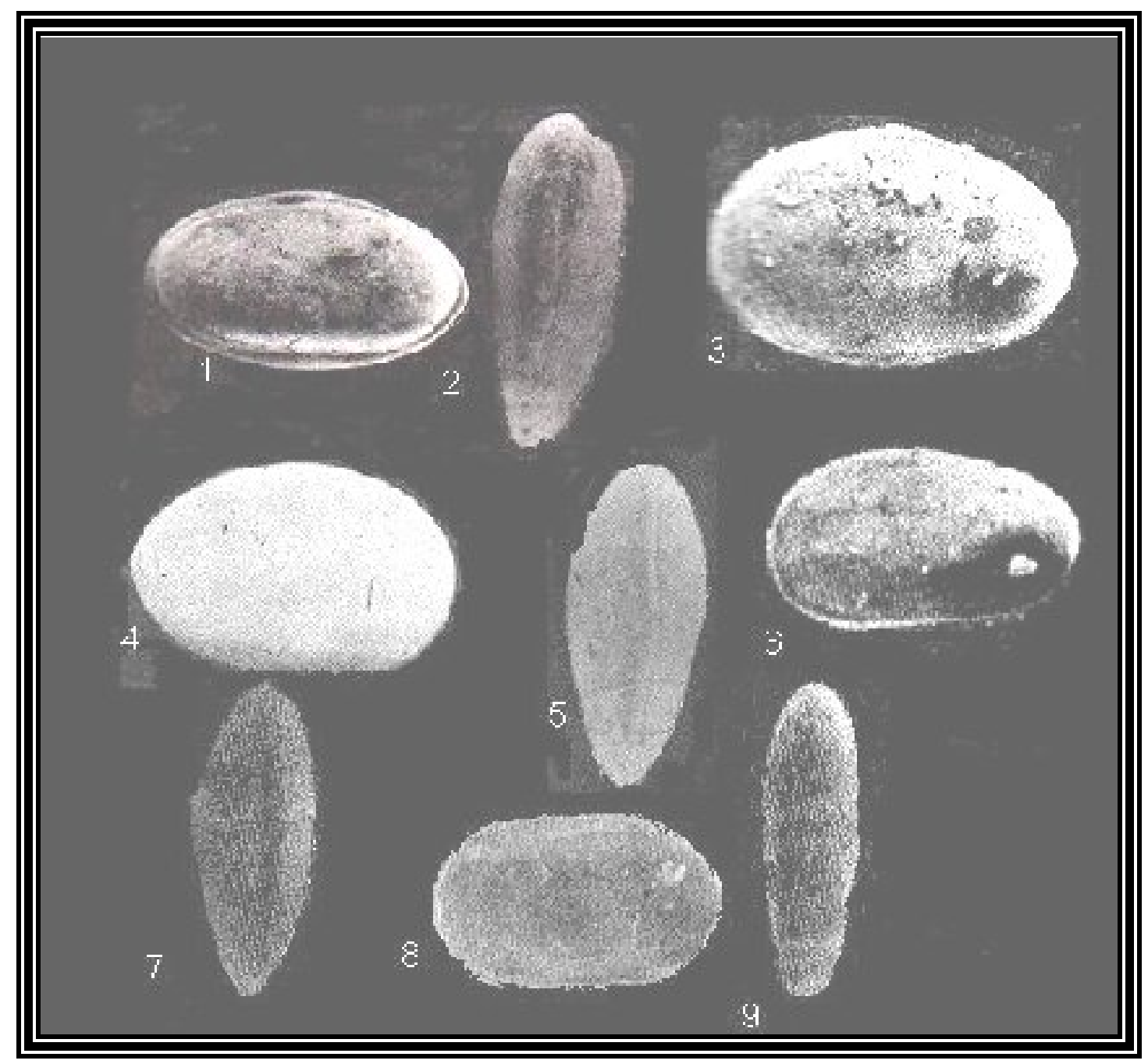

